\title{
Nova economia do narcisismo
}

\section{Colette Soler}

Não acreditem que meu título venha do fato de que peguei o vírus da novidade a qualquer preço, o que caracteriza nossa época. Não é absolutamente o caso, pois não gosto realmente dessa epidemia. Estou trabalhando sobre esse tema a partir de duas fontes. Primeiramente, faz muito tempo que tenho impressão de que aquilo que retivemos do ensino de Lacan, essencialmente antes dos anos 1965, não permite pensar nem responder às evoluções da época em todos os níveis - dos costumes, das estruturas sociais, dos instrumentos técnico-científicos. Dito de outra maneira, acho que os instrumentos teóricos da prática dos analistas não são atuais neste início de século. Tampouco são atuais quanto a Lacan, pois como ignorar que ele mesmo operou mudanças de perspectivas consideráveis? Essa mudança é considerável no que concerne o narcisismo. Primeiro, colocou-o por conta do imaginário, isso é notório, mas um imaginário subordinado à cadeia do simbólico. Porém, a partir de 1973, ao longo de suas lições, ele repetiu continuamente que as três consistências - Imaginário, Simbólico e Real - são equivalentes e não subordinadas umas às outras, como antes havia afirmado.Pois bem, concluí que não somente é preciso apreender as razões dessas mudanças, que não são arbitrárias, mas, sobretudo, é preciso repensar, em todo caso tornar atual, tudo aquilo que desenvolveu sobre a base dessa primeira tese de um simbólico relativo à linguagem que ordena e, portanto, subordina tudo o que se apresenta no imaginário, em primeira posição o lugar do narcisismo e da consistência imaginária do eu, em contraste com a divisão própria do sujeito do significante.Observem os esquemas L e R, o texto sobre Schreber e o grafo do desejo, são límpidos: todos eles desdobram, visualizam e topologizam esse postulado que, seguindo essas elaborações, chamei anteriormente de "imagem serva" de um simbólico soberano. De fato, após Função e Campo da Fala e da Linguagem, Lacan (1953/1998) subordinou o imaginário do espelho ao simbólico da linguagem, assim como o significado é subordinado ao significante. Em consequência disso, sublinhou que a presença do Outro, grande Outro, condiciona mesmo o fato de a criança se reconhecer e se amar na sua imagem. Quando, com o nó borromeano, ele reconsidera e recusa essa subordinação, quando martela que as três consistências são autônomas e equivalentes, como não se perguntar o que isso muda no plano clínico e analítico?

Vejam o que está em jogo. Antes de qualquer exame, podemos colocar a questão: se o imaginário não é subordinado ao simbólico, como poderemos continuar a pensar que o narcisismo do eu seja redutível pelo simbólico e que uma análise, 
ao construir o sujeito dividido do significante, reduzirá as pretensões narcísicas? O desafio analítico é muito importante tanto quanto a concepção que se faz do homem, que Lacan vai escrever UOM, a partir de sua hipótese que define a estrutura, não a estrutura da linguagem, mas a estrutura dita "efeito da linguagem" sobre o ser vivo. O que isso muda? Primeiramente, na concepção daquilo que está no cerne do imaginário, do qual Lacan partiu, ou seja, a função do espelho, e, em seguida, no campo das significações que pertencem ao registro do imaginário ordenado pelo simbólico, como o significado é subordinado ao significante. O que é um imaginário autônomo e qual a diferença entre subordinação e enodamento eventual no nó borromeano?

\section{O que está no jogo do espelho}

O que está em jogo para Lacan e para o sujeito? Parto do início e da evidência: o espelho é primeiro. Para marcar as balizas do percurso de Lacan, sublinho imediatamente que construí essa fórmula a partir do modelo de uma outra que se encontra na "Conferência sobre Joyce” (LACAN, 1975a/2003): o SKbelo" é primeiro.

No ensino de Lacan, não somente o estádio do espelho se situa em seus antecedentes, mas, além disso, segundo sua tese, ele é igualmente primeiro para a criança. Ele é mesmo anterior ao sujeito. Vou retomar isso.

Depois da tese sobre Aimé e sua psicose, O estádio do espelho (LACAN, 1949/1998) é seu texto principal, jamais colocado em causa, embora completado e remanejado - deixo de lado o texto sobre a família (LACAN, 1938/2003), um pedido de Henri Wallon. Ora, chamo a atenção que, no texto do estádio do espelho faltam duas grandes referências que poderíamos esperar, pois nem Narciso, o mito, e, sobretudo, nem Freud são evocados. O que será que isso indica? Penso que isso nos coloca na pista de uma questão implícita que subentende o texto de Lacan. Não há leitura de um texto teórico, que seja de filosofia ou de psicanálise, de que não se possa extrair a questão que o texto procura resolver. Aliás, Sobre o narcisismo: uma introdução, de Freud (1914/1985), assim como o mito de Narciso, vêm resolver a questão do posicionamento da libido erótica, o que chamamos de investimento dos objetos ou relação de objeto, noção célebre da psicanálise no início de Lacan. A questão subjacente ao estádio do espelho é um tanto defasada em relação a essa problemática, sendo mais ampla. Certamente neste estádio, a imagem se torna o primeiro objeto; então podemos ver aí um estádio da libido, porém esse amor da imagem é determinado por outra coisa, a saber, a função identitária: ela é constituinte de um primeiro estrato da identidade. Daí podemos dizer o que

1 No original, SKbeau, jogo de palavra com o termo escabeau, que é traduzido por escabelo em português. Cf. Joyce, o Sintoma. In: Outros escritos. Rio de Janeiro: Jorge Zahar Ed., 2003, p. 560. 
é a questão fundamental, implícita, à qual responde o estádio do espelho: saber como a criança, que é um pequeno organismo, um pequeno animal, se torna um humano socializado e socializável. É outra questão distinta daquela de Freud, que pressupõe a humanidade da criança como dada. Mas era também a questão dos psicólogos da época, especialmente Wallon, que havia pedido a Lacan seu artigo sobre a família, pois, no fundo, todos estavam preocupados com o advento do humano socializado ou socializável propriamente dito. Daí o interesse apaixonado pelas crianças selvagens. Lacan estava nesse eixo que era do seu tempo.

Aqui a identificação é reconhecida como o instrumento primeiro da socialização. O que será que funda a importância, e até mesmo a necessidade dessa primeira identificação no pequeno homem? Era preciso que Lacan colocasse essa questão, visto que a imagem tem aí uma função distinta no animal, que aparentemente não toca nem à sobrevivência nem à reprodução. Em sua tese mais geral e a mais conhecida, embora posterior, Lacan responde: a identificação é necessitada pelo efeito da falta-a-ser do sujeito que a linguagem produz. Mas para a criança que ainda não usa lalíngua - a linguagem é isso, o uso da lalíngua - não pode ser o caso. Lacan vai procurar outra causa e se referir a uma causa real, ou seja, aos efeitos da prematuração do nascimento no animal humano, com o despedaçamento das funções vitais que ocorre nos primeiros anos, e que ele supõe produzir uma experiência de "insuficiência" que a identificação ao Um da imagem, "ortopédica em sua totalidade" (LACAN, 1949/1998, p. 100), resolveria, antecipando a solução que só virá de fato pela maturação do sistema nervoso. Para dizer a verdade, nada indica esse mal-estar na criança, é o contrário. Freud (1914/1985) é mais convincente quando, no início do texto Sobre o narcisismo: uma introdução, coloca que o que precede a unidade do eu não é um doloroso sentimento de insuficiência repercutindo a imaturidade das funções adaptativas, mas um autoerotismo que pode se dizer feliz, satisfeito, o prazer obtido no próprio corpo, em derivação das funções vitais, certamente múltiplas, mas cujo despedaçamento não é sinônimo de mal-estar vital, desde que a demanda do Outro não venha se misturar. A psicanálise encontra certamente as fantasias e as angústias do corpo despedaçado, porém em analisantes, adultos ou crianças, cuja unidade do eu já está estabelecida. Aliás, não vemos como poderia ter aí uma consciência do despedaçamento sem uma consciência da unidade, pois são relativas uma à outra. Mais tarde, Lacan não deixou de zombar de sua construção e de brincar de seu apelo à prematuração, no momento em que colocou em evidência que o verdadeiro princípio do corpo despedaçado não é a prematuração, mas o significante.

A identidade pela identificação evidentemente é uma identidade alienada, feita de um primeiro semblante. Lacan insistiu suficientemente sobre esse traço da alienação à imagem e da aspiração correspondente de se liberar dessa alienação, com a esperança de que isso fosse possível. Essa esperança surtiu efeitos devasta- 
dores na psicanálise lacaniana em seu início, encorajada por Lacan ao construir a oposição entre a enfatuação narcísica do eu e o sujeito dividido do significante.

Com essa identificação escópica, notem que o projetor de Lacan é dirigido, curiosamente, sobre o que há de mais estrangeiro ao inconsciente, ou seja, o registro daquilo que se vê. Era preciso que Lacan tivesse uma outra questão insistente para ser assim. Ele especifica que essa imagem é o "limiar do visível" que abre assim o registro escópico, núcleo de todo parecer. Aqui se trata de ver, e Lacan não toma de Freud, mas da etologia que estabeleceu o que não é absolutamente um mito, mas uma função vital, bem real, da imagem visualmente percebida no animal. Qual será sua função no animal? Primeiramente, uma função de transmissão entre as gerações animais de nada menos que o saber instintual. Esse saber instintual opera em dois planos. Ele é necessário primeiramente para a sobrevivência - o pinto só cisca quando vê a galinha ciscar - em seguida intervém naquilo que assegura a reprodução da espécie, que vai junto com os rituais da parada visual; e o peixinho de rio não se reproduz sem a imagem da espécie, porém a sua imagem no espelho funciona tão bem quanto a de um congênere. Para a criança, diferentemente do animal, a imagem não serve nem à sobrevivência, que é assegurada pelo Outro devido à prematuração;nem ao sexo, que só vem mais tarde. Sua função é de identificação, fornecendo o núcleo do amor de si, da libido e da identidade fusionando nessa ocasião com a imagem do próprio corpo. E isso muito antes de toda problemática sexuada. Ela precede diacronicamente não a lalíngua, que é um banho de origem, mas a aquisição da linguagem. Trata-se da criança que ainda não fala, Lacan sublinha esse ponto.

Nada disso evoca o inconsciente, o que é surpreendente! É somente na sequência desse estádio do espelho, num segundo tempo, em A causalidade psíquica, que Lacan (1946/1998) repensa o inconsciente freudiano. Faz isso a partir da função da imagem, limiar do mundo visível, previamente verificada de modo experimental pela observação, não pela fala - e a observação é um outro ponto de amarração no pensamento científico, distinto de Freud, a amarração experimental - e avança um inconsciente-imago, feito de imago originárias, aquelas das primeiras relações experimentadas no contexto dos primeiros anos. Portanto,um inconsciente feito das primeiras marcas sociais, além de um set de imagens fixas que, em razão de sua fixidez, já são vizinhas do significante.

Essa colocação em suspenso da questão do inconsciente se concebe, pois nessa fase do espelho, o sujeito ainda não fez sua "entrada no real" (LACAN, 1960b/1998, p. 661). Trata-se de uma fase anterior ao sujeito. A expressão anterior ao sujeito pode surpreender, pois estamos habituados a dizer, com Lacan, que antes mesmo de nascer a criança é sujeito para o Outro. Sim, "fazer dele sujeito no dizer de seus pais" (LACAN, 1972/2003, p. 460), diz Lacan em O aturdito, e é um prejuízo a priori. Certamente a priori visto que os efeitos prejudiciais desse dizer são pro- 
gramados antes mesmo de a criança existir e independentemente do que serão suas próprias características, especialmente quanto ao sexo, quer seja menino ou menina. Que nasça hermafrodita para ver, exclama Lacan! No entanto, é preciso fazer a diferença entre ser sujeito do dizer de Outro e ser sujeito "no real". Cito: "É preciso que à necessidade [...] venha somar-se a demanda, para que o sujeito [...] faça sua entrada no real, enquanto a necessidade transforma-se em pulsão [...]" (LACAN, 1960b/1998, p. 661).

Ele só entra no real, ou seja, sai do Outro, com a demanda articulada como primeira forma de um dinamismo libidinal induzido não pela imagem especular do transitivismo, mas pela linguagem, geradora ao mesmo tempo do sujeito e das pulsões. O transitivismo é mais uma confusão de imagens do que uma ordem entre as imagens, e é a linguagem evidentemente que vai infundir retroativamente na imagem o estatuto de um diferencial próprio ao significante.

\section{Um outro narcisismo}

Quais serão as funções para o sujeito desse narcisismo da imagem tal como percebemos nessa primeira elaboração? Falaram-me de uma frase muito bonita de Oscar Wilde: "o amor de si é um amor que dura toda a vida" (WILDE, 1993, p. 239), portanto mais confiável que os outros. Vale a pena pensar nisso.

A primeira função que sublinhei é uma função identitária. A criança se reconhece nessa imagem. Evidentemente, toda função identitária supõe o Um, aqui é o Um da Gestalt da imagem, precedendo o Um do significante. Então, o narcisismo, se devemos lhe dar uma definição simples a partir do mito, é o amor de si mesmo, um si mesmo identificado pela unidade dessa imagem, independentemente de suas outras características, e especialmente de sua beleza, só contando sua unidade gestáltica, como acentuou Lacan.

Como todo amor comporta uma dimensão de idealização, indo até suas variantes de idealização: a superestimação, a vaidade, a enfatuação. Ele "se acha”, o pequeno narciso. Às vezes isso beira a loucura; o delírio megalomaníaco é seu lado derrisório, e cada vez é surpreendente quando se constata, por exemplo, o quanto a autoavaliação satisfeita pode até se esconder atrás daquilo que se apresenta como uma falta de confiança em si, especialmente nas mulheres. Não vou insistir mais, é um dos motores tragicômicos da vida social, mas quero sublinhar outra coisa.

Primeiramente, o narcisismo dessa fase é do amor, não do desejo, nem da pulsão; e a introdução dessas duas dimensões na experiência vai obrigar Lacan a repensar ou a tornar complexa essa noção. Marquei a diferença com Freud que, desde o início, situa o narcisismo no nível de um avatar do desejo sexual e das pulsões. Mas Lacan disse que, quando se ama, não tem nada a ver com o sexo. Então, no fundo, o narcisismo do espelho, o amor de sua imagem, é em si mesmo ainda muito incompleto, pois em cada um existe algo que se prefere à sua imagem. 
Disse que a questão de Lacan, advinda de seu trabalho sobre os psicóticos, era a socialização da criança. Ora, desde 1949, Lacan faz da identificação narcísica, paradoxalmente em relação à ideia que fazemos disso, a matriz da primeira função socializante, não o sublinhamos bastante sobre isso. Ele estabeleceu uma continuidade entre a imagem do corpo próprio e a imagem do semelhante;isso é conhecido, e a função que atribui à identificação transferida ao semelhante é explícita. Vejam nos Escritos (LACAN, 1949/1998, p. 101) - vou resumir as citações: "o estádio do espelho inaugura, pela identificação com a imago do semelhante [...] a dialética que desde então liga o eu a situações socialmente elaboradas", e evoca em seguida "uma mediatização pelo desejo do outro", sem maiúscula, mediatização constituinte dos objetos do desejo. Já estava atribuindo ao transitivismo narcísico uma função que vai além da contemplação da imagem, e que inclui aí o desejo mesmo, em todo caso os apetites dos falantes que, numa só palavra, faz paradoxalmente do narcisismo um dos princípios do social.

Entretanto, fico espantada com o contraste com o mito que não diz absolutamente a mesma coisa do que a psicanálise. Com efeito, desde os primeiros passos do mito, origem do termo, Narciso se situa fora da relação. Conhecemos o núcleo da hystória relatada por Ovídio. No início, Narciso (1992) é um caçador solitário, indiferente, totalmente insensível aos charmes das ninfas que sua beleza cativa, especialmente à ninfa Eco. Poderíamos comentar sobre seu nome que faz dela um reflexo sonoro e não visual. Então, Narciso é autossuficiente, hoje diríamos $a$ narcissistic personality, e Freud diria talvez narcisismo primário, até que Nêmesis, a vingança, o faça encontrar, para sua infelicidade, seu próprio reflexo na água, sendo desde logo cativado por ela, tornando-se seu único objeto. Ele entra, então, em relação com a imagem que dá um golpe em sua autossuficiência, um objeto mortalmente inacessível. Vejam a inversão.

Por outro lado, o mito implica que não esperamos pela psicanálise para perceber o que há de mortífero na imagem, mas, sobretudo, saber que a posição heterossexual da libido é sujeita a fracassos. Pois, no fundo, o erro de Narciso no mito é sua não relação com o outro sexo e não com o semelhante, que não é sexuado. $\mathrm{O}$ mito, com esse encontro da imagem do corpo próprio, ilustra o que posso chamar de uma espécie de maldição da imagem, ou, mais ainda, uma maldição da relação. Para Narciso, essa imagem libidinalizada se substitui à presa que até então era sua causa, até mesmo o objeto de seu desejo de caçador, desejo separador que o subtraía da libido heterossexual, o colocava ao abrigo de outra maldição, aquela do sexo. O estádio do espelho de Lacan substitui em parte essa dimensão da maldição da imagem, mas de outro lado positiva sua função socializante de relação ao semelhante. Essa defasagem tem relação com as ameaças que pesavam nos laços sociais na época de Lacan, bem diferente da época da pólis grega.

Hoje, o narcisismo da imagem tomou uma dimensão inimaginável, e inimaginavelmente ativa em relação ao passado recente. Assistimos a uma verdadeira cultura 
da imagem, pensem na prática do selfie (temos o espelho no bolso) e todas as técnicas atuais de fabricação dos corpos imaginários, primeiramente com as normas em uso da silhueta, com a indústria da moda que o recobre, a cirurgia estética que o transforma, mas também a nutrição que lhe dá volume. Sem esquecer das práticas de marcação do corpo de objetivo distintivo, que vão das tatuagens até o body art. Não se pode parar de enumerar, com os novos poderes de manipulação da imagem graças à técnica, o valor novo que o sujeito hoje confere à sua imagem tomada como um índice de identidade. Uma identidade que se mostra, que se oferece a ser vista, à margem do que não se pode ver do sujeito. Os psicanalistas que lidam com sujeitos que falam e não se mostram têm tendência a denunciar esses novos fatos da civilização. No entanto, é preciso não esquecer que, desde sempre, os paradoxos da identidade encontraram seu motor essencial na disjunção entre o ser real e o parecer, o parecer que se desdobra entre parecer da imagem, o parecer fotográfico de certa maneira, e o que aparece de não fotográfico na significação pela via simbólica, ou seja, os ideais do eu de Freud e do Outro maiúsculo de Lacan, grande I do Grande A - I(A) - que decidem, entre outras coisas, do valor das imagens. Vejam o grafo do desejo. Essa disjunção do real e do parecer não é uma descoberta da psicanálise, nem tampouco alienação dos indivíduos no parecer. "Eu é um outro", fórmula conhecida anteriormente. E não será um grande tema do analisante? De um lado, se interroga para detectar como é visto, o que "acham dele", e de outro lado protesta "não sou o que você pensa - aqui tomo emprestado do discurso comum a pequena história daquela que acham que é uma coquete e que se insurge, desmentindo isso, mas de outro lado se esforça em coincidir com a imagem ideal que, no entanto, lhe dá o sentimento de ser despossuída de si mesma.

Assim, não há somente o que se vê, mas aquilo que não se vê, ou seja, como o outro me vê. Sublinhei o fato de que Lacan utiliza, em 1960, a expressão "narcisismo do desejo" (LACAN, 1960a/1998, p. 742), distinto do "narcisismo do ego", que é seu protótipo, diz Lacan em Diretrizes para um congresso sobre a sexualidade feminina. O que é "narcisismo do desejo"? É um narcisismo que, como aquele do ego, tem uma função identitária. Eis porque esse último é o protótipo. Mas, com o desejo introduzimos o registro do sexo onde justamente falta o que faria a identidade homem-mulher. Lacan introduz esse narcisismo do desejo num parágrafo sobre as mulheres, onde coloca que, o que determina a frigidez é a identificação ao "padrão fálico". Isso consiste em erigir ao nível do parecer o significado do falo, que de natureza é recalcado, e cujo recalque tem como efeito de projetar todas as manifestações do sexo no parecer. Não é o parecer da simples imagem escópica, do selfie, é o parecer da ostentação e da mascarada, todo o jogo da comédia dos sexos, para convocar no parecer aquilo que não se vê. $\mathrm{O}$ que faz aqui unidade identificadora no final não é a imagem, mas um significante, o falo, significante da falta e com ele um imaginário ampliado até incluir, além da forma do corpo, o conjunto das significações do sexo no discurso. Logo, o espelho não é mais 
simplesmente uma superfície física própria a devolver um reflexo visual, como me expressei faz tempo, é um “ espelho falante”. Aquele que Lacan figura em seu esquema ótico. "Espelho, diga-me se sou a mais bela?" Portanto, é um espelho suposto saber. Certamente suposto saber o que escapa à minha vista, e mais amplamente, o que escapa a toda vista possível e que não pertence ao registro da visão, mas de saber como o Outro me olha, ou seja, “o que sou para ele?”. Aqui se abre um outro capítulo da infelicidade de Narciso: aquela de sua não suficiência.

\section{As infelicidades de Narciso}

Narciso está longe de ser autossuficiente, está à mercê do espelho, sob o duplo aspecto que já disse. Nos dois níveis, o da imagem que se mostra e do desejo que não se vê, não se enuncia, mas que aparece bem, pois ele se escuta na fala e se percebe na ação. O espelho é o Outro que se torna presente pelos outros, e paradoxalmente coloca o pequeno Narciso do estádio do espelho à mercê do desconhecido, pois subordina a relação à imagem primária, à relação ao Outro barrado, que Santo Agostinho, na sua famosa frase, já tinha tomado a dimensão. Então, seria preciso abrir o capítulo das infelicidades de Narciso que, desde já alienado a uma imagem que não é ele, além disso é encadeado a um olhar heterotópico - bem longe de ser autossuficiente. Esse olhar pode estar em todo lugar e em nenhum lugar, pois o que seria uma imagem que ninguém veria ou uma significação que não seria de ninguém? Não é surpreendente que um Deus foi inventado que vê tudo, as imagens e para além de sua significação e de seu sentido. Não é surpreendente também que, às vezes, se sonhe com o contrário, o manto de invisibilidade, fantasia, sem dúvida, propícia ao voyeur e outras astúcias da perversidade, mas propícia primeiramente à subtração que o liberaria. Não é surpreendente, enfim, que se batalhe, que se esforce tanto para se assegurar da possessão de uma imagem que não depende de mim, pois seu valor vem do Outro e do qual posso ser despossuído, e que, no entanto, produz a paixão, entre outras a inveja e o ciúme. Por fim, não é surpreendente, e mais essencial, que se aspire ao que permitiria uma separação. Toda a questão é saber se há um narcisismo de separação possível e qual seria seu instrumento se não é a imagem, nem o desejo, pois estes se sujeitam ao outro, sem maiúscula, ou ao Outro, com maiúscula.

\section{Narciso e os outros}

Com efeito, qual seria a relação ao semelhante que o narcisismo preside, do qual sublinhei que é a matéria-prima do social? Que relação preside em sua aspiração a, digamos "se fazer belo?" Belo para o olho de qualquer outro, sem maiúscula. É a tática do "você me viu?" Essa fórmula com dois pronomes pessoais, que Lacan apreciava tanto, inclui a necessária dimensão relacional do narcisismo e indica bem 
a dependência de Narciso. Neste aspecto, o selfie é notável. O sujeito se acha bem interessante para se mirar num verdadeiro espelho, mas em seguida é preciso enviar o selfie a alguns outros para se mirar no olho desses outros. Numa ilha deserta, o selfie não teria nenhuma utilidade, podemos pressentir, e é por isso que não dizemos "não esqueça do espelho", mas se pergunta "que livro levaria para a ilha?", porque o espelho do Outro é um espelho verbal que não exige a presença do corpo. Não há Narciso fora de uma relação de sedução em todo caso. O personagem do sedutor ou da sedutora não tem boa reputação, mas é porque confundimos com o infiel, Don Juan, ou a provocante. Apesar disso, a sedução é uma forma de demanda, e o analisante não escapa disso, muito pelo contrário, na sua fala transferencial só faz "manobrar" o espelho do Outro para parecer amável e, por conseguinte, se achar amável. O que será melhor do que a experiência da transferência para se assegurar que o amor de si se sustenta do amor recebido do Outro?

Por conseguinte, o outro lado da relação aos outros é a competição. "Espelho diga-me se sou a mais bela", pois não basta ser bela, mas a mais bela. Isso é próprio das mulheres. Nesse nível as paixões primárias se inflamam, a inveja enfurece de receber menos, ainda Santo Agostinho, o ciúme fulmina e lamenta de ser excluído de um laço de amor, real ou suposto, a rivalidade combate com a vontade de vencer. Acho bastante inútil ridicularizar e deplorar essas paixões malvadas, basta a religião cristã, para isso não precisa da psicanálise. Por outro lado, não deveríamos esquecer que a forma mais eminente de competição é a emulação na qual a afirmação de si é menos destruidora do outro que produtora, pois podem brotar obras da civilização, essas produções que tanto encantavam Freud rebatizando essa fecundidade do termo de sublimação. Lacan, no final de seu ensino, acabou aceitando essa sublimação e com uma palavra: escabelo.

\section{Um outro narcisismo}

O escabelo redefine o narcisismo, é o instrumento de um narcisismo ativo, combatente e produtor; portanto, é mais do que o amor de si, é a afirmação de si, eventualmente pela via da oferta à civilização. No nível da experiência, o escabelo é aquilo com que cada um tenta se fazer valer para seduzir o olho do outro. Que a imagem seja o primeiro veículo dessa identificação narcísica indica uma prevalência do visível para o humano, a questão é saber até onde ela se iguala à prevalência do sonoro da linguagem. Na diacronia das ditas fases do desenvolvimento nos habituamos a ordenar os registros pulsionais, que aparecem ao mesmo tempo em que o sujeito no real, começando pelo oral e o anal, que correspondem aos dois objetos da demanda do Outro; e em seguida o olhar e a voz, objetos do desejo do Outro, cuja presença faz signo. Mas, no fundo, voz e olhar estão desde a origem; eles não seguem diacronicamente a nutrição e a educação dos esfíncteres. 
A criança é envolvida neles desde o nascimento, pois falamos com ele, olhamos para ele desde o primeiro momento da vida do recém-nascido.

Essa preeminência do escópico avançada no espelho foi como velada pelo alargamento da categoria do imaginário. A partir de A instância da letra, Lacan (1957/1998) identifica o imaginário ao significado da cadeia da linguagem, o que faz com que dependa fundamentalmente de outra coisa do que do visível, isso faz com que dependa do significante e, por consequência, a função da imagem especular foi eclipsada pelo campo do significado, pela significação e pelo sentido. Mas, até onde o olho que vê, portanto, o visível, depende do significante? A imagem do espelho, que se situa antes do sujeito, é o limiar do mundo visível, dizia Lacan em seu texto de 1949. A incidência própria do visível ficou como uma questão na expectativa com a promoção por Lacan de um imaginário homologado ao significado da cadeia significante. É esse imaginário que é subordinado à cadeia do significante, assim como a significação do falo, significante da falta, era colocado nessa primeira construção como subordinado ao significante do pai. Mas a questão é recolocada quando Lacan afirma que o imaginário não é subordinado. Vou voltar a isso.

O primeiro instrumento do escabelo é a imagem visível, mas os instrumentos são múltiplos. Além da imagem ajeitada da qual falei, são também todas as performances de exceção em todos os domínios da cultura, a começar pela agricultura, mas também a ciência, os jogos esportivos e certamente a arte. Demonstração eminente de Joyce, mas se ele é uma exceção, não é porque conseguiu se fazer um escabelo, mas pela maneira como o fez, como estabeleci em meu livro Lacan, leitor de Joyce (2015). O escabelo é próprio do falasser e ele "é primeiro", segundo Lacan, já falei sobre isso. Ele retoma o narcisismo do espelho, mas acrescenta esse outro narcisismo da invenção. O escabelo é o espelho repensado e completado com o narcisismo do desejo, ou mesmo do gozo.

Se vocês têm dúvidas, retomem o trabalho sobre as duas primeiras páginas da $2^{\text {a }}$ conferência Joyce, o Sintoma (1975a/2003), a partir do seminário O sinthoma (197576/2007). Digo retomar o trabalho, pois isso se lê não somente palavra por palavra, mas fonema por fonema, e cada um desses fonemas sendo escritos neologicamente, mostra que é a letra gráfica que decide do sentido a dar ao som, como se mostra nas diversas escritas da palavra escabelo. Com escabelo, mesmo se não falam francês, vocês escutam três sons, três fonemas que não têm sentido em nossas línguas e, conforme a escrita, o sentido muda. Em Hescabelo (Hessecabeau), a letra h é muda, não se escuta, porém, evoca o h de homem, enquanto os " $\mathrm{s}$ " evocam o verbo ser. Ou ainda, SKbelo (SKbeau) com duas letras alfabéticas, fora do sentido em nossas línguas. Falta só um equívoco gráfico, vejam isso, aquele que jogaria sobre a escrita do som "beau" que poderia se escrever simplesmente com duas letras alfabéticas

2 Em francês beau (belo) tem o som /Bo/. 
- b-a-bá, se aprende na escola - b, o, bo, fora do sentido. Essa omissão indica que Lacan quis guardar a referência ao lado escópico que comporta a escrita $b, e, a, u$, beau (b,e,l,o, belo) para designar a bela forma do espelho de onde partiu vinte anos antes, aquela que o homem adora, como ele diz, e é explícito quando escreve Helessecrêbelo (hissecroibeau), em que escutamos ressoar o narcisismo da imagem. Mas a escrita Helessecrêbelo (hissecroibeau) acrescenta outra coisa. Ela injeta o verbo hisser - "oh hisse", se diz em francês para significar o esforço que é preciso para elevar sua imagem ou seu nome de alguns degraus. Não se poderia dizer melhor a face laboriosa do narcisismo que, longe de somente se contemplar, deve se esforçar e não se contentar com as imagens, mas se fazer produtor em alguma coisa. Lacan explicita: "UOM seumaniza à larga" (LACAN, 1975a/2003, p. 560). ${ }^{3}$ Seumanizar (se lomelliser) é neológico, não existe em francês, mas diz que o homem, para ser homem, deve trabalhar a "se fazer" homem. Por que isso? Com efeito, não se sabe se no reino animal existe algum equivalente que, para ser tigre, por exemplo, precise se "tigrilizar". UOM deve se seumanizar (se lomelliser) porque ele vive do ser (= esvazia o ser). ${ }^{4}$ Eis um tema do início que retorna, constante: é a fala que introduz a questão do ser e que, no mesmo movimento, cava nele uma falta. É este efeito da fala que condiciona a necessidade do escabelo, o fato de colocar a questão do ser para o falante. O escabelo, portanto, é próprio do homem, e não uma característica somente de alguns; e ele é primeiro, começando com o espelho, mas indo para além até a promoção do nome. O escabelo é para todos, mas, apesar disso, todos os escabelos não valem a mesma coisa do ponto de vista da socialização. Tudo depende dos meios e dos produtos.

Existem figuras do antiescabelo. Aquele que renunciou, por princípio ou por acidente; aquele que desistiu, que renunciou a se sehumanizar (se homelliser). É preciso ver em cada caso, o que muitas vezes pode ser enganador. A prova disso temos na megalomania melancólica: o sujeito grita bem forte que não vale nada, mas também bem forte que ninguém se iguala a ele nesse aspecto. Ele seumaniza (se lomellise) de sua nulidade inigualável que não pode se confundir com os afetos da falta de autoestima, como se diz. A falta de autoestima não tem mais poder causal do que a maioria dos afetos, isso é patente; especialmente nas mulheres, que muitas vezes atestam desse afeto de insuficiência e do sentimento de falta, ou mesmo de impotência, ainda mais quando são engajadas na competição fálica, outro nome da competição narcísica. Mas, enquanto isso, constatamos que não deixam a mesa do jogo, e mesmo ganham a aposta - embora tremendo, nos asseguram disso muitas vezes. Aqui, acreditamos nelas pela metade, pois é uma meia-verdade já que a Verdade só pode se meio-dizer.

3 Em francês: "LOM se lomellise à qui mieux mieux"

4 Aqui, trata-se de um jogo de palavras que têm o mesmo som: vit de l'être (vive o ser)e vide l'être (esvazia o ser). (N. do T.) 


\section{Os três narcisismos}

No que diz respeito aos meios que evoquei, depois do narcisismo da imagem e o narcisismo do desejo, existe também o do gozo. Isso faz três. Lacan introduziu o narcisismo do desejo a propósito da relação entre os sexos, como aquilo que permite, no fundo, de "se crer" homem ou mulher, e isso passa pelo modo de relação ao falo que evidentemente supõe a fala. Podemos ampliar sua definição. $O$ narcisismo do desejo consiste em se identificar aquilo que empurra você na vida, geralmente sem saber o que empurra, é isso o desejo. Sua forma mais notável é "não ceder sobre seu desejo", ou seja, ficar firme sobre seu ser de desejo, também opaco, mesmo que seja desviante. Vejam a ironia da história dos analistas, pois é justamente o que idealizamos como o contrário do narcisismo depois do seminário A ética da psicanálise (LACAN, 1959-60/2008). Ora, Antígona, que não cede, é o narcisismo do sujeito, outra maneira de dizer aquele do desejo, e de fato, no que concerne de se fazer um escabelo na memória dos homens, ela conseguiu, pagando o preço de sacrificar todos os atrativos da vida. E depois desse seminário, com Os quatro conceitos fundamentais da psicanálise (LACAN, 1964/1985), idealizamos "a diferença absoluta" do fim de análise. Mas a diferença absoluta é o absoluto da afirmação de si e sancionada pelo desejo do outro, o analista. Em resumo, depois disso tudo, continuar a dizer ou a deixar entender que uma análise, de uma maneira ou de outra, devia promover um para além da aspiração a fazer valer seu próprio ser, definição ampliada que retenho para o narcisismo, fazer valer seu próprio ser, é consequência de uma denegação coletiva impressionante, signo, sem dúvida, da recusa de saber, o que Lacan diagnosticou nos analistas (LACAN, 1975b/2003).

Quando Lacan, continuando seu avanço, evocou a "identificação ao sintoma”, em que se trata de gozo, além de acrescentar que é um tanto sucinto, quando falou das unaridades disparatadas, houve, eu não diria um despertar, mas ao menos uma inquietude nos analistas especificamente quanto à ordem social e às relações aos outros. Com efeito, esse passo introduz uma radicalização.

Até aqui podíamos desconhecer a ameaça que o narcisismo faz pesar sobre o laço social, pois o desejo, sendo desejo do outro, o narcisismo do desejo não era tão associal assim. Com o narcisismo do gozo, que consiste em não ceder sobre a afirmação de sua modalidade de gozo e a se identificar, ou seja, não ceder sobre a preferência que cada um tem à sua própria; pois bem, as coisas mudam, pois o gozo, contrariamente ao desejo, não é determinado pelo Outro, o lugar da linguagem, mas pelos acidentes da conjunção entre lalíngua e o corpo. Eu, pessoalmente, já insisti bastante sobre esse ponto. Então, vem a questão: o que pensar do poder analítico da fala de verdade, sempre meia-dita sobre as fixões de gozo? O 
que pensar dos sujeitos produzidos pela análise que chegou ao fim? Não poderiam esses sujeitos identificados ao seu gozo ser uns sobre-narcisos, dessa vez tão autossuficientes quanto Narciso antes de encontrar sua imagem? E o que pensar do laço social, pois o gozo não enlaça?

Seria esquecer que a autossuficiência é impossível a quem fala como tal; ora, mesmo o narcisismo do escabelo vem da fala. O resultado é que não há meio de se seumanizar (se lomelliser) sozinho. Foi o que comecei a falar em Medellín. Certamente o gozo depende do "Existe o UM", mas desde que o escabelo é primeiro e inevitável, precisa de uma corte como a do rei Sol. Não há meio de se fazer um escabelo sem o outro. O "você me viu?" se dá a ver, é o paradigma do laço internarcísico, mas existem outros modos, como sabemos, pois Joyce é mais "você me leu?". Então, esses modos têm que ser estudados em cada caso, para as pequenas vidas minúsculas que também têm seu escabelo, assim como para os mais preeminentes. Tudo isso para dizer que a questão dos laços sociais, para além do declínio dos discursos que hierarquizam, está aberta. Esse é o primeiro ponto. Essa revisão supõe que cessemos de opor pulsões e narcisismo, como geralmente se faz, considerando que as pulsões buscam algo do lado do outro, sem maiúscula, enquanto o narcisismo não sairia de seu perímetro imaginário. O escabelo é mais do que a construção da imagem de si, não é simplesmente a estátua erigida que Lacan evocava no seu início; ele não é dado antecipadamente, é preciso se fazê-lo. Como o "se fazer" da pulsão, fórmula de Lacan para a definição da pulsão, poderia contribuir à ereção do escabelo, é evidentemente uma questão. Se, como disse Lacan, LOM faz pagar um dízimo ao outro, é porque sai do perímetro de sua imagem escópica, e, se vocês me seguiram, as pulsões devem ser incluídas nesse narcisismo ampliado, tanto quanto elas são no amor em geral e em todas as relações de objeto. "Em ti mais do que ti", dizia no fim do Seminário 11 (LACAN, 1964/1985). Pois bem, com o narcisismo do escabelo é preciso acrescentar “em mim mais do que mim". Dito de outra maneira, é um narcisismo que deve contar com o objeto $a$, o invisível como eu o chamo, que falta a todo gozo. A imagem é primeira, mas para o falante ela é casulo, envelope do objeto subtraído, e isso se aplica à imagem de si tanto quanto à do outro.

Fica a questão da autonomia do imaginário. Avançando com o nó borromeano, ela engaja a autonomia do visível, pois a imagem escópica é seu núcleo. O que será que faz Lacan recusar a subordinação do imaginário ao simbólico? É sua redefinição do simbólico, digamos do inconsciente, que é explícita "contrariamente ao que disse", o inconsciente não é uma cadeia significante. Ele é uma série, e não uma cadeia, mas uma série numérica, uma série de significantes que são igualmente unidades numéricas, cada uma solidária do objeto a que falta. Essa mudança da definição se deve a Lacan que, se interrogando para além da cadeia 
da fala sobre a relação do sujeito ao significante (sujeito que entrou no real), produziu a fórmula sempre repetida, o significante é o que "representa o sujeito para um outro significante". Pois bem, o inconsciente são os significantes que não representam o sujeito, que vêm da lalíngua e que afetam seu corpo. São elaborações de De um Outro ao outro (LACAN, 1968-69/2008) e de textos periféricos em que formula o inconsciente é um "saber sem sujeito". Estou lembrando sucintamente essa guinada para indicar que ele funda a mudança de afirmação sobre a ideia antiga de uma subordinação do imaginário à cadeia e que recoloca a questão do peso da imagem nela mesma.

Deixei a questão em suspenso, mas acho que já estava presente para Lacan. Tenho como prova os desenvolvimentos de 1964 sobre o olho e o olhar no Seminário 11 (LACAN, 1964/1985) na ocasião da morte de Merleau Ponty. Ele a elabora de uma maneira nova, e quando nota que somos todos seres olhados, que o mundo é oni-voyeur (omni voyeur), ${ }^{5}$ não é para afirmar uma paranoia generalizada, mas uma prevalência específica do registro do visível e abrir a questão de sua relação com a divisão do sujeito.

Mas além do seminário O sinthoma, curiosamente Lacan (1975-76/2007) retoma a questão: porque o homem é tão enfatuado de sua imagem? Digo curiosamente, pois poderíamos pensar que tinha a resposta. Ele deu duas, como disse, a da prematuração, e depois a da divisão do sujeito, do objeto que falta à completude que a imagem recobre. Que retome a questão me leva a pensar que essas respostas não lhe pareciam suficientes. Esse ponto importa, pois algo está em jogo: aquele da avaliação das variantes do escabelo.

Tradução: Maria Vitoria Bittencourt

\section{Referências bibliográficas}

FREUD, S. (1914) Introducción del narcisismo. In: Obras Completas de Sigmund Freud. Buenos Aires: Amorrortu, 1985. v. 14.

LACAN, J. (1938) Os complexos familiares na formação do indivíduo. In: Outros escritos. Rio de Janeiro: Jorge Zahar Ed., 2003.

. (1946) Formulações sobre a causalidade psíquica. In: Escritos. Rio de Janeiro: Jorge Zahar Ed., 1998.

. (1949) O estádio do espelho como formador da função do eu. In: Escritos. Rio de Janeiro: Jorge Zahar Ed., 1998.

. (1953) Função e campo da fala e da linguagem em psicanálise. In: Escritos. Rio de Janeiro: Jorge Zahar Ed., 1998.

5 Oni é um prefixo latino que significa todo. 
. (1957) A instância da letra no inconsciente ou a razão desde Freud. In: Escritos. Rio de Janeiro: Jorge Zahar Ed., 1998.

. (1958) A direção do tratamento e os princípios de seu poder. In: Escritos. Rio de Janeiro: Jorge Zahar Ed., 1998.

(1959-60) O seminário, livro 7: a ética da psicanálise. Rio de Janeiro: Jorge Zahar Ed., 2008.

(1960a) Diretrizes para um Congresso sobre a sexualidade feminina. In: Escritos. Rio de Janeiro: Jorge Zahar Ed., 1998.

. (1960b) Observação sobre o relatório de Daniel Lagache: Psicanálise e estrutura da personalidade. In: Escritos. Rio de Janeiro: Jorge Zahar Ed., 1998. . (1964) O seminário, livro 11: os quatro conceitos fundamentais da psica-

nálise. Rio de Janeiro: Jorge Zahar Ed., 1985. . (1968-69) O seminário, livro 16: de um Outro ao outro. Rio de Janeiro: Jorge Zahar Ed., 2008.

. (1972) O aturdito. In: Outros escritos. Rio de Janeiro: Jorge Zahar Ed., 2003. (1975a) Joyce, o Sintoma. In: Outros escritos. Rio de Janeiro: Jorge

Zahar Ed., 2003.

(1975b) Introdução à edição alemã de um primeiro volume dos Escritos. In: Outros escritos. Rio de Janeiro: Jorge Zahar Ed., 2003.

- (1975-76) O seminário, livro 23: o sinthoma. Rio de Janeiro: Jorge

Zahar Ed., 2007.

OVÍDIO. Les métamorphoses. Paris: Gallimard, 1992.

SOLER, C. Lacan, lecteur de Joyce. Paris: PUF, 2015.

WILDE, O. Collected works of Oscar Wilde. London: Routledge, 1993.

\section{Nova economia do narcisismo New economics of narcissism}

\section{resumo}

Este texto indica uma renovação do conceito de narcisismo a partir das mudanças introduzidas por Lacan, calcadas no advento da teoria do nó borromeano. Para isso, a autora demonstra como o registro imaginário foi revisto por Lacan quanto à sua subordinação ao simbólico. Retomando o Estádio do Espelho, aponta quais as consequências dessa nova leitura sobre o conceito de narcisismo, estabelecendo três narcisismos: da imagem, do desejo e do gozo. Assim, a autora propõe uma nova economia do narcisismo por meio da releitura do mito de Narciso, de um estudo sobre o escabelo, em que a dimensão do imaginário é ampliada com a inclusão do objeto $a$. Essa concepção tem efeitos consideráveis para a questão dos laços sociais em atualidade. 


\section{palavras-chave:}

Narcisismo; estádio do espelho; imaginário; escabelo.

\section{abstract}

This text indicates a renewal of the concept of narcissism as of the changes introduced by Lacan, based on the advent of the Borromean node theory. For this, the author demonstrates how the imaginary record was reviewed by Lacan regarding its subordination to the symbolic. Resuming the Mirror Stage, she points out the consequences of this new reading on the concept of narcissism, establishing three narcissisms: the ones of image, desire and joy. Thus, the author proposes a new economy of narcissism through the re-reading of the myth of Narcissus, of a study on the stool, in which the imaginary dimension is enlarged with the inclusion of the object $a$. This conception has considerable effects on the issue of current social ties.

\section{keywords:}

Narcissism; mirror stage; imaginary; escabeau.

\section{Recebido:}

30/05/2017

\section{Aprovado:}

01/07/2017 